\title{
32. MAGNETIC AND MINERALOGICAL INVESTIGATIONS OF OPAQUE MINERALS: PRELIMINARY RESULTS ${ }^{1}$
}

\author{
Maureen B. Steiner, California Institute of Technology, Division of Geological and Planetary Sciences, \\ Pasadena, California ${ }^{2}$
}

\begin{abstract}
Preliminary investigation of the non-crustal igneous material recovered at Site 462 suggests that it is fairly similar to crustal oceanic basalt and low-temperature-oxidized only to a relatively small degree. Curie points are between 150 and $350^{\circ} \mathrm{C}$, somewhat lower than expected for Early Cretaceous material. The massive nature of much of the basaltic column is probably the reason for the low degree of oxidation and hence the lower Curie temperatures.

Microscopic examination of these rocks in reflected light shows relatively little evidence of low-temperature oxidation: they have only minor staining and cracking of the $\mathrm{Fe}$-Ti oxide grains. High-temperature oxidation is evident in the central portions of some of the thick sills. Preliminary electron-microprobe analyses suggest that the composition of the least oxidized titanomagnetites within these rocks is about the same as that of oceanic crustal material.
\end{abstract}

\section{INTRODUCTION}

The intrusive and extrusive igneous rocks within the sedimentary strata above basement at Site 462 are compositionally very similar to the material comprising the oceanic crust (Batiza et al., this volume). At least part of the column of igneous material appears to belong to the Early Cretaceous, because of its extrusive nature (Site Summary, this volume) and its association with Lower Cretaceous (Barremian) sediments. That the extrusive and the overlying intrusive material have similar compositions and similar abundances of rare-earth elements suggests that the whole igneous column may be approximately the same age (Batiza, this volume). Because these igneous rocks are Cretaceous and similar to oceanic crustal material, investigation of their magnetochemical properties may add to the current body of information on the magnetic mineralogy of the oceanic crust. Currently, only limited information exists for older oceanic crustal basalt, i.e., Cretaceous and older. For that reason, the $\mathrm{Fe}-\mathrm{Ti}$ oxides in these rocks have been investigated using a combination of magnetic and mineralogical techniques.

The studies are still in progress, but it seems appropriate to report preliminary results here. Techniques used include measurement with a thermomagnetic balance, reflected-light microscopy, and electron microprobe analyses. The very large grain size of some of this material (occasionally up to 100 to $300 \mu \mathrm{m}$ ) makes these rocks particularly easy to analyze with the microprobe, a technique often prohibited by the small grain size of many oceanic basalts. At present, 37 Curie temperatures have been measured. Twenty-eight of the same samples have been examined in reflected light. Thus far, four of these have been analyzed on the electron microprobe. All samples are those for which paleomagnetic information has been obtained (see Steiner, this volume).

\footnotetext{
1 Initial Reports of the Deep Sea Drilling Project, Volume 61.

2 Initial Reports of the Deep Sea Drilling Project, Volume 61.
Present address: University of Wyoming, Laramie, Wyoming.
}

\section{THERMOMAGNETIC DATA}

Curie temperatures have been measured on two instruments, one at the United States Geological Survey in Menlo Park and the other at the University of Wyoming. One comparison sample has been analyzed on both instruments. The comparison suggests that agreement between the two instruments is very good (Table 1, Sample $51-1,24 \mathrm{~cm}$ ). The instrument at Menlo Park is an automated recording magnetic balance (Doell and Cox, 1965; Grommé et al., 1969). All samples were measured in vacuum (less than $10^{-4}$ torr) with heating to 610 to $615^{\circ} \mathrm{C}$. Samples were 4 -mm-diameter cores (600-700 mg). Heating and cooling rates were $10^{\circ} \mathrm{C} /$ min. One sample was treated in nitrogen to check the improvement in determination of low Curie temperatures. (The design of the Menlo Park apparatus requires the presence of gas for accurate determination of low Curie temperatures. See Grommé and Mankinen, 1976). There was no obvious significant difference between results obtained in vacuum and in nitrogen. The University of Wyoming balance is built around a Cahn microbalance. Five samples were measured on this instrument. Samples were treated in vacuum between $10^{-5}$ and $10^{-4}$ torr. Small chips (totaling $150-200 \mathrm{mg}$ ) were heated and cooled at rates of 25 to $30^{\circ} \mathrm{C} / \mathrm{min}$. All Curie temperature values were determined using the graphic method of Grommé et al. (1969).

The 37 thermomagnetic analyses are listed in Table 1, along with paleomagnetic information for each sample (from Steiner, this volume). Both heating $\left(T_{c_{1}}\right.$ and $\left.T_{c_{2}}\right)$ and cooling $\left(T_{c_{C}}\right)$ temperatures are listed. Almost all $(68 \%)$ of the temperature curves obtained for this hole are "semi-reversible"; that is, the cooling curve traces a path similar to the heating curve, but is usually displaced somewhat from it. Figures 1A, 1B, and 1C illustrate the behavior typical of $51 \%$ of the samples. The term "semi-reversible" is used to describe this similarity of the heating and cooling curves because, although the traces are not truly reversible, they are more similar to reversible curves than to irreversible ones. 
Table 1. Curie temperatures.

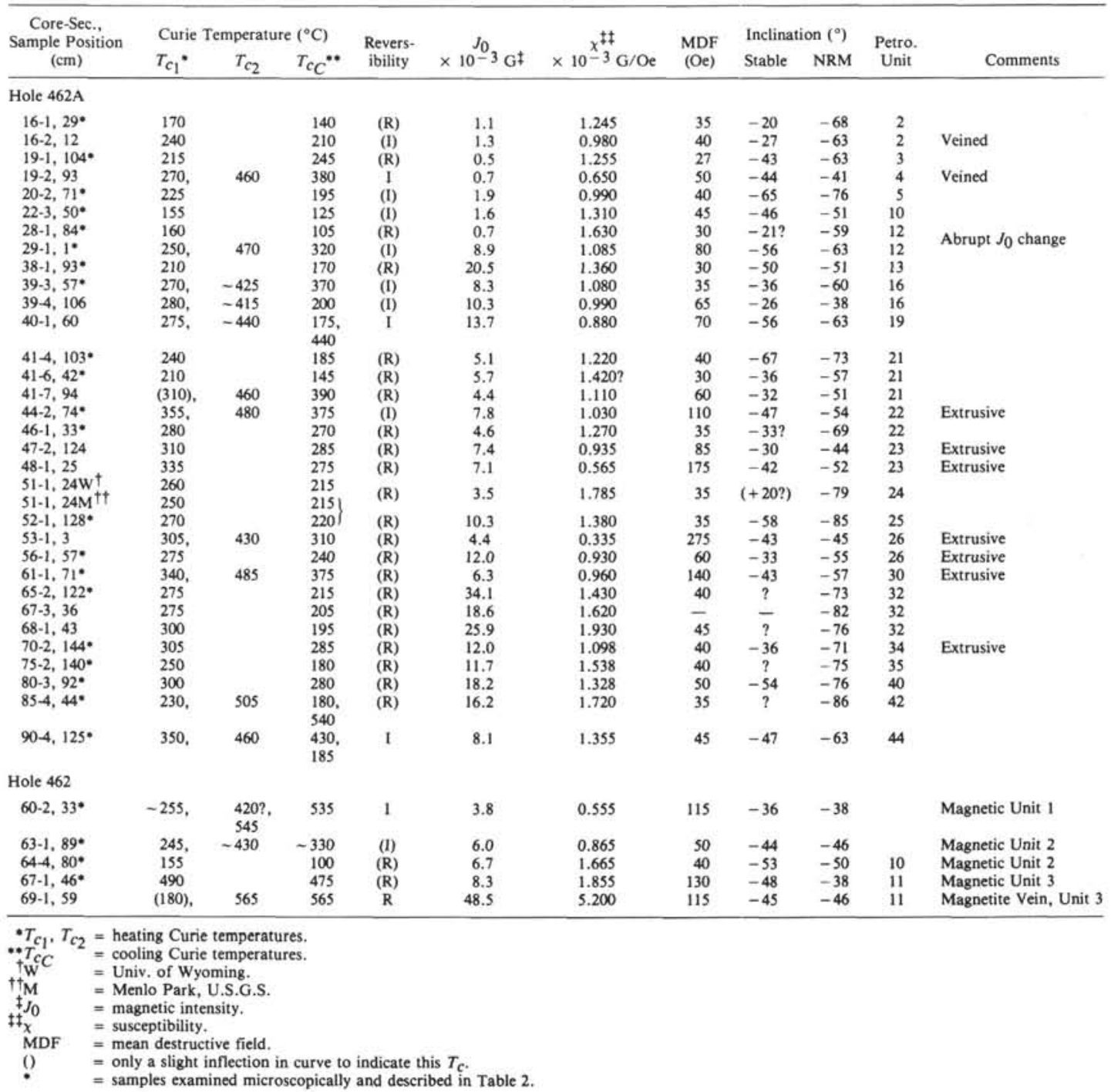

Most of the samples $(92 \%)$ had magnetic moments upon cooling that were within $0.02 \mathrm{emu} / \mathrm{g}$ of the moment before heating. A most interesting feature of these curves, however, is that almost all $(\mathbf{8 1 \%})$ showed lesser moments after heating compared with before heating. Only seven samples showed any increase in moment after heating, and only two of these showed increases of more than $0.01 \mathrm{emu} / \mathrm{g}$ over the moment before heating. Both the semi-reversible shape of the curves and the return to nearly the same magnetization after heating appear to suggest that these basaltic rocks are oxidized relatively little.

The samples not represented by Figures $1 \mathrm{~A}-1 \mathrm{C}$ showed some evidence of two phases. Five samples yielded high-temperature semi-reversible Curie temperatures, as shown in Figure 1D. Three of these five samples contain ilmenite lamellae in titanomagnetite, visible through a microscope in reflected light (to be discussed later). The other two samples have yet to be examined. Four of these five samples yielded two Curie points when heated. The fifth has a single high-temperature semi-reversible Curie point with a tiny hint of a lower temperature phase. The two Curie temperatures may be explained by the microscopic observation that these samples contain a mixture of titanomagnetite grains: some in which there is extensive development of ilmenite lamellae (and thus a more titanium-free magnetite), and others in which such oxidation-exsolution has not occurred or has not progressed to any great degree.

Most of the rest of the samples showed evidence of phase splitting on heating, as illustrated in Figures 1E-1G. However, production of a high-Curie-temperature phase in most of these appeared only as a very small inflection at the high-temperature end of the heating curve, as shown in Figure 1E. Moreoever, all evidence of two phases disappeared upon cooling (Figs. 1D-1G) in all samples. The combination of the disappearance of the second phase, the almost consistently lower Curie temperatures, and smaller moments after heating is striking. The curves in Figures $1 \mathrm{~F}$ and $1 \mathrm{G}$ emphasize 

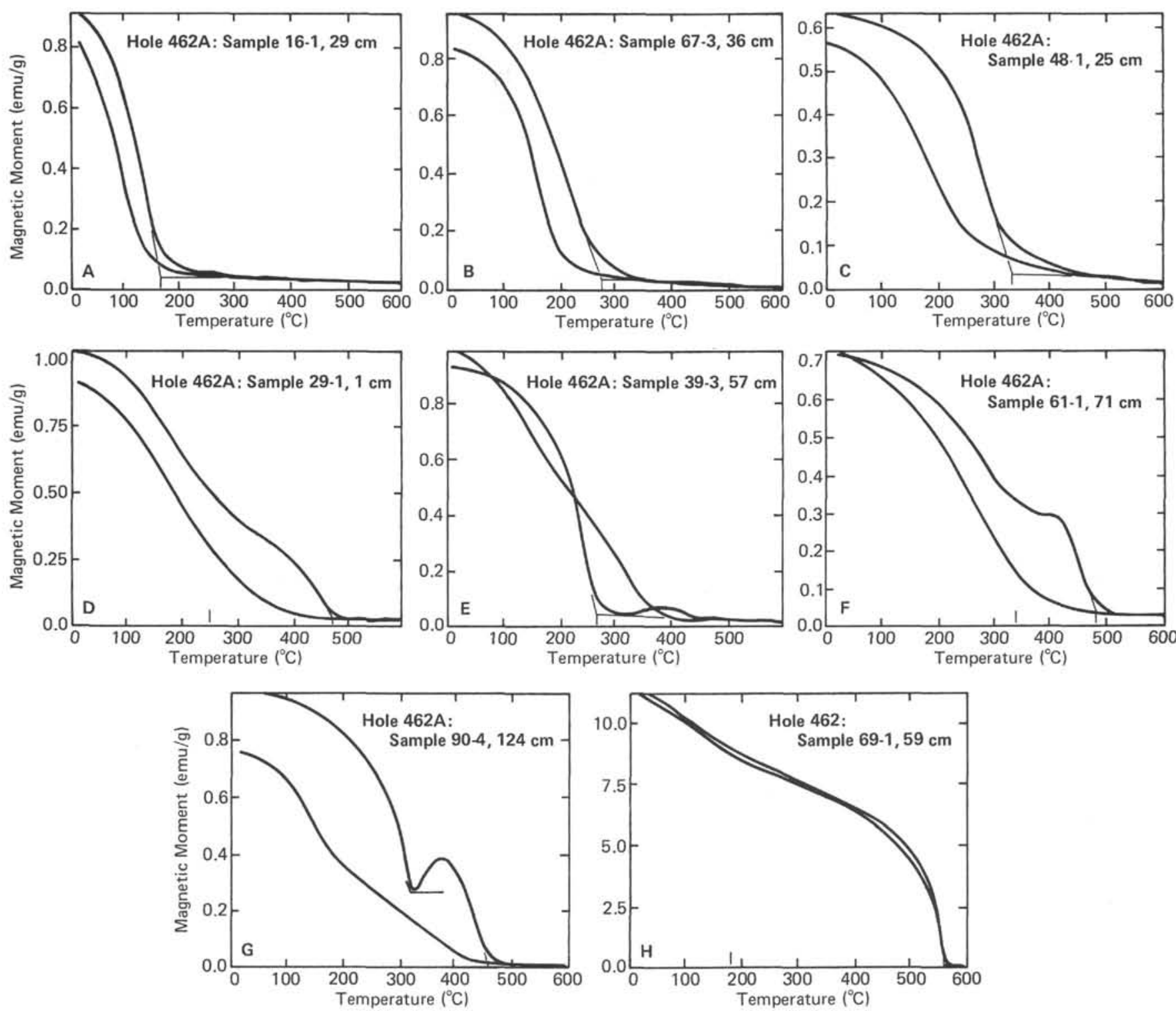

Figure 1. A-C. Typical thermomagnetic curves for Holes 462 and 462A. D. High-temperature semi-reversible thermomagnetic curve. E, F. Thermomagnetic curves depicting the relatively uncommon occurrence of two phases. G. Two-phase thermomagnetic curve showing pronounced loss of the two-phase characteristic upon cooling. H. Thermomagnetic curve of the magnetite vein from Hole 462 (see text).

these characteristics. These characteristics have been observed with two different thermomagnetic balances, both of which have clearly recorded irreversible-type behavior in other studies. These data seem to suggest very low oxygen fugacities during heating, such that the unmixed phases are partially reduced and remix back into titanomagnetite (Marshall, 1978; Freer and Hauptman, 1978). This may be a consequence of the fact that these igneous samples have probably been intruded and extruded into highly reduced sediments from the Cretaceous anoxic events. Two episodes within the Cretaceous saw the production of highly oxygen-deficient sedimentary sequences (Schlanger and Jenkyns, 1976). It is likely that the igneous materials at issue here were emplaced into these sediments. Perhaps original low oxygen fugacities produced by these circumstances were maintained during heating in vacuum in the laboratory.
More work is being directed toward a clearer understanding of this behavior.

Vein magnetite occurs at the bottom of the pilot hole (Hole 462). One large and a couple of small veins show octahedrons of magnetite. These veins are deemed to be late-stage magmatic (Batiza et al., this volume). They occur at the center of a very thick $(51 \mathrm{~m})$ sill. Nowhere else in the basaltic column was vein magnetite found. A sample of the large vein and the cross-cut basalt gave a Curie temperature $\left(T_{c}\right)$ of $565^{\circ} \mathrm{C}$, as shown in Figure $1 \mathrm{H}$. Another phase $\left(T_{c}-180^{\circ} \mathrm{C}\right)$ is also suggested in the initial part of this curve, during both heating and cooling. The suggestion of a low-temperature phase is corroborated by a sample, from approximately the same position in Hole 462A, which appears to penetrate the same sill (Sample 28-1, $84 \mathrm{~cm}$ ). It has a Curie temperature of $160^{\circ} \mathrm{C}$ (see Fig. 2A). Within the immediate 

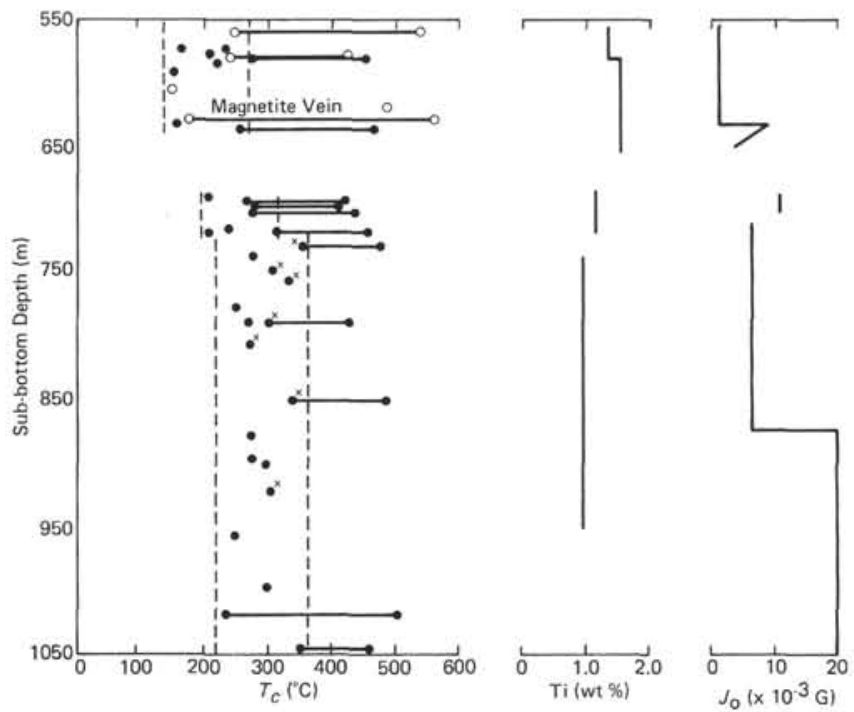

Figure 2. Hole $462 \mathrm{~A}$ values of Curie point plotted against depth in hole. Schematic illustrations of averaged whole-rock titanium content (wt. \%) and NRM paleomagnetic intensity $\left(J_{0}\right)$ respectively, are plotted adjacent to the Curie temperatures. Curie temperatures for Hole 462 are also shown (open circles). (The depths of the lowest three samples from Hole 462 have been adjusted to fit the magnetic and petrologic correlation between Holes 462 and 462A.) Crosses adjacent to Curie points indicate extrusive samples.

vicinity of the magnetite vein, a sample taken 8 meters above the vein has a reversible high-temperature thermomagnetite curve, $T_{c}=490^{\circ} \mathrm{C}$ (Sample 462-67-1, 46 $\mathrm{cm}$, Table 1). In Hole $462 \mathrm{~A}$ material, a sample from about 5 meters below Sample 28-1, $84 \mathrm{~cm}$ (mentioned previously) contains a phase with $T_{c}=470^{\circ} \mathrm{C}$. Both of these high-Curie-temperature $\left(400^{\circ} \mathrm{C}\right)$ samples also contain ilmenite lamellae, implying high-temperature oxidation.

Figure 2 shows the Curie point data plotted against depth. As this figure indicates, Curie temperature increases with depth. Samples from the top 75 meters of the igneous sequence have the lowest Curie temperatures. These do not all have the same stable inclination, but belong to three different magnetic units. The interval between these and the lower extrusives appears to be intermediate in Curie temperature, as it was also intermediate in magnetic inclinations. The Curie temperatures of material taken below the uppermost occurrence of extrusive rocks (indicated by crosses, Fig. 2) are distinctly higher than those of material from the purely intrusive interval above. This difference is complicated by a difference in inclination between these two parts of the section. The extrusive rocks themselves (see crosses in Fig. 2) have Curie temperatures fairly tightly grouped between $305^{\circ}$ and $355^{\circ} \mathrm{C}$. They are generally the highest temperatures for this lower portion of the section. This probably reflects the higher degree of low-temperature oxidation which usually occurs in finer grained rocks.

The three groups of Curie temperatures delineated in Figure 2 correspond, interestingly, to three separate groups of whole-rock titanium content. The titanium values, measured by X-ray fluorescence on board ship
(Site Summary, this volume), are schematically diagrammed in Figure 2. The addition of titanium to the crystal lattice of titanomagnetites results in lower Curie temperatures. Thus, the correlation of Curie temperature and titanium content may mean that the variation in titanium content in the melt is also reflected in opaque minerals. The correlation also may be fortuitous, however, since Curie temperature is controlled not only by titanium content but also by degree of lowtemperature oxidation. Microprobe work now under way will attempt to answer this question.

Figure 2 also shows a schematic representation of the NRM intensities of the basalt samples, from the paleomagnetic study by Steiner (this volume). The correlation of NRM intensity with this apparent correlation of Curie temperatures and whole-rock titanium values is poor, and indicates that, as has been observed many times before in DSDP studies, a variety of influences bear upon the NRM intensity observed (see, for example, Day et al., 1979). A general trend is evident in Figure 2, however. NRM intensities are lowest in the upper part of the section, where Curie temperatures are lowest and titanium content highest. Intensities are considerably higher in the lower part and, correspondingly, Curie temperatures are higher and titanium values lower. Again, it appears that the whole-rock titanium content may be reflected in the titanomagnetites.

Coercivity has not yet been measured for these samples. However, median destructive field (MDF) strengths of the natural remanence, determined from the paleomagnetic investigation, have been plotted against Curie temperature. Figure 3 shows the relationship between $\mathrm{MDF}$ and Curie temperature. This figure is similar to a plot of coercivity versus Curie temperature by Johnson (1979a) for samples from Leg 45. The transition to higher coercivities occurs at about the same Curie temperature of about $250^{\circ} \mathrm{C}$. Thus, the association of increased magnetic hardness with higher Curie temperature, noted in many previous DSDP investigations, is also evident here.

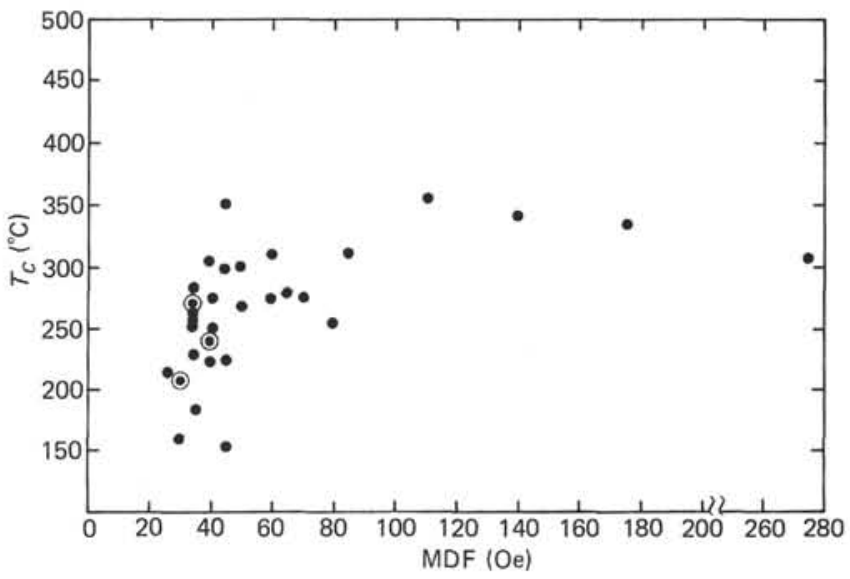

Figure 3. Relationship of median destructive field strength to Curie temperature. Open circle around filled circle indicates two samples at that point. Note break in scale beyond $200 \mathrm{Oe}$. 


\section{OPAQUE MICROSCOPY}

Samples were examined with a Zeiss microscope in reflected and transmitted light. Magnification was generally $\times 1250$. Samples were polished at room temperature, avoiding any of the usual techniques involving elevated temperatures used in making polished thin sections. All samples were viewed with an oil immersion lens without any filters on the light sources. The 28 polished sections examined are described in Table 2.

The terms used in the descriptions in Table 2 refer to the majority of grains (70-100\%) in a sample, unless otherwise specified. The degree of cracking of the grains, the amount of staining around them, and the amount of sulfides now present are all visible indicators of the extent to which low-temperature oxidation has proceeded in and around the original titanomagnetite grains (Johnson, 1979b; Honnorez et al., 1978; Eisenach, 1978; Hall and Fisher, 1977; Ade-Hall, et al., 1976). All samples in this study have been oxidized to some degree at low temperatures, such that the original titanomagnetites are now (cation-deficient) titanomaghemites. For brevity, they will be referred to as TM.

Three categories of TM grain shape were observed in this suite of igneous rocks. "Skeletal" grains have the crosses and fishbone patterns reflecting incipient titanomagnetite crystal growth. A few grains typical of this shape category are shown in Figure 4A. These occur in all extrusive samples examined (samples from Hole $462 \mathrm{~A}$, Cores $44,56,61$, and 70 , Table 2). Skeletal grains were also observed in Hole 462A samples from Cores 20, 52, 89, 90, and in Hole 462 samples from Cores 60 and 63 (Table 2). Those samples represent either chilled sill margins or very thin sills. Some extremely large skeletal grains have been observed in thus study. Examples are shown in Figures 5A and 5D. "Semiskeletal" is a term used to describe grains whose shape still reflects growth from the original skeletal shape, but which have grown beyond the initial cross shapes. These shapes are illustrated in Figure 4B (also in Figs. 7A, 5D, $5 B)$. "Anhedral"' grains lack a regular shape, as shown in Figure 5B, 6A, 6C, 7B, and 7C.

Cracking of grains presumably reflects volume changes as low-temperature oxidation proceeds (Ade-Hall et al., 1976). Cracking is described here as slight, moderate, or extensive, in a relative sense among these samples. Slight cracking is illustrated in Figures 5A and 4B, and consists of less than about four crack per grain. Moderate describes grains with about 5 to 9 cracks per grain (Fig. 5B). Extensive cracking is illustrated by Figure 5C. Extensive cracking with significant widening of the cracks and replacement of the spinel with nonopaque material is separated from the category of " $\mathrm{ex}$ tensive" cracking, and is shown in Figure 5D. This condition is evident in only two samples: one from the upper part of Hole 462 (the sample from core 63, Table 2), and one from the bottom of Hole $462 \mathrm{~A}$ (the sample from core 90 , Table 2 ). This more extensive oxidation may have a counterpart, however, in very small grains, in the form of corroded grains. Cracking is rare in samples with very small grain size; instead, the grains frequently appear to have dark coatings on them, and sometimes look corroded (Fig. 5E). In general, most of the samples in this study are only slightly to moderately cracked; only a few have extensive cracking. This suggests that only a relatively small amount of lowtemperature oxidation has occurred in most samples.

The frequent abundance of sulfides in these samples is another indication that low-temperature oxidation has not proceeded very far. Two types of iron sulfides are obvious in many of the sections; these are tentatively identified as pyrrhotite and pyrite, although no microprobe work has been done. A few samples contain only pyrite as the iron sulfide. This is particularly true in those with extensive cracking. Sulfides are listed very generally in Table 2, as either abundant or scarce. The grains commonly have globular shapes, but some with crystalline terminations are also present. The grains occur both as free grains and attached to TM. In some slides, sulfide grains are exceedingly large, from $40 \mu \mathrm{m}$ to $70 \mu \mathrm{m}$. In one sample (462A-61-1, $71 \mathrm{~cm}$; Table 2) several very large skeletal growths of pyrite occur intimately intergrown around (completely enclosing) skeletal TM. The association of magnetite or titanomagnetite growing in a circular pattern around globular sulfides is frequent in these samples. Generally, such grains appear to have the same reflectivity as the rest of the TM in the slide-with one exception: In sample 85, near the bottom of the hole, the TM associated with the globular sulfides was distinctly darker gray than the rest of the TM in that slide.

The origin, and therefore significance, of such magnetite or titanomagnetite is not currently agreed upon as either primary or secondary. Ade-Hall et al. (1976) report one such occurrence to be almost titanium-free magnetite, possibly resulting from incomplete high-temperature oxidation of pyrrhotite to pyrite. Eisenach, however (1978), reports such a grain which contains nearly the same amount of titanium as the normally occurring TMs of that sample and of oceanic basalts in general. The observations in this study may tentatively be taken to suggest that, in general, the two occurrences have similar compositions. Only one observation suggests that they may be of different composition. Planned microprobe studies may define all this more clearly, however.

Other accessory opaques were relatively rare in these samples. Chromian spinels occur in two samples (462A$46-1,33 \mathrm{~cm}$ and $462 \mathrm{~A}-51-1,24 \mathrm{~cm}$; Table 2); in one of these they occur with TM overgrowths. Free ilmenite was almost never observed. Ilmenite on the edges of TM grains and as patchy intergrowths within TM observed, however, in several samples. Ilmenite lamellae-evidence of high-temperature oxidation-are also present, generally in the same samples in which the other ilmenite occurs. The degree of lamellar development varies from extremely slight (only one or two isolated, incomplete lamellae in a grain) to extensive growth of parallel lamellae along all three (111) planes. Figures 6A-6C illustrate the patchy ilmenite growth and its fringing occurrence on TM. Figure $6 \mathrm{C}$ also illustrates the development of a weak lamella. The association of 
Table 2. Opaque-mineral descriptions.

\begin{tabular}{|c|c|c|c|}
\hline $\begin{array}{l}\text { Core-Sec., } \\
\text { Sample Position } \\
\quad(\mathrm{cm})\end{array}$ & $\begin{array}{l}\text { Curie } \\
\text { Temp. } \\
\left({ }^{\circ} \mathrm{C}\right)\end{array}$ & Description & Ti-Magnetite Grain Size \\
\hline \multicolumn{4}{|l|}{ Hole 462A } \\
\hline $16-1,29$ & 170 & $\begin{array}{l}\text { Semi-skeletal to anhedral; cracking slight; staining very slight; } \\
\text { abundant sulfides; one free grain of ilmenite; some magnetite } \\
\text { overgrowth on magnetite. }\end{array}$ & $\begin{array}{l}5 \text { to } 20 \mu \mathrm{m} \text { and } 30 \text { to } 50 \mu \mathrm{m} \text {, } \\
\text { larger are present to } 100 \mu \mathrm{m} \text {. }\end{array}$ \\
\hline $19-1,104$ & 215 & $\begin{array}{l}\text { Anhedral; cracking slight to moderate; no staining; } \\
\text { reasonably abundant sulfides; ilmenite rimming magnetite } \\
\text { grains-tiny lamellae occasionally, no free ilmenite. }\end{array}$ & $\begin{array}{l}20 \text { to } 40 \mu \mathrm{m} \text { and } 50 \text { to } \\
160 \mu \mathrm{m} \text {. }\end{array}$ \\
\hline $20-2,71$ & 225 & $\begin{array}{l}\text { Skeletal and semi-skeletal; cracking slight; no staining; } \\
\text { abundant sulfides. }\end{array}$ & 1 to $40 \mu \mathrm{m}$. \\
\hline $22-3,50$ & 155 & $\begin{array}{l}\text { Semi-skeletal; moderate cracking: some slight staining; } \\
\text { abundant sulfides. }\end{array}$ & 0.25 to $90 \mu \mathrm{m}$. \\
\hline $28-1,84$ & 160 & $\begin{array}{l}\text { Anhedral; slight (to moderate) cracking; no staining; abundant } \\
\text { sulfides; ilmenite growth in and on magnetite, patchy ilmenite } \\
\text { lamellae. }\end{array}$ & 2 to $250 \mu \mathrm{m}$. \\
\hline $29-1,1$ & (255) 470 & $\begin{array}{l}\text { Anhedral; slight cracking; no staining; moderate amount of } \\
\text { sulfides, both globular and crystalline shaped; ilmenite } \\
\text { lamellae, also ilmenite rimming and as patches in magnetite. }\end{array}$ & 4 to $80 \mu \mathrm{m}$. \\
\hline $38-1,93$ & 210 & $\begin{array}{l}\text { Anhedral and semi-skeletal; slight cracking; slight staining; } \\
\text { abundant sulfides. }\end{array}$ & 20 to $140 \mu \mathrm{m}$. \\
\hline $39-3,57$ & 270,425 & $\begin{array}{l}\text { Anhedral and semi-skeletal; cracking moderate to extensive, } \\
\text { many well filled cracks; some slight staining in parts; } \\
\text { moderate amount of sulfides. }\end{array}$ & 10 to $140 \mu \mathrm{m}$ (but cracked). \\
\hline $41-4,103$ & 240 & $\begin{array}{l}\text { Anhedral to semi-skeletal; extensive cracking; very slight } \\
\text { staining around heaviest cracking; moderate amount of } \\
\text { sulfides, generally corroded in appearance. }\end{array}$ & 10 to $160 \mu \mathrm{m}$. \\
\hline $41-6,42$ & 210 & $\begin{array}{l}\text { Anhedral; moderate cracking; no staining; abundant sulfides, } \\
\text { very frequent association of magnetite ringing sulfides. }\end{array}$ & $\begin{array}{l}\text { Some } 5 \text { to } 40 \mu \mathrm{m} \text {, commonly } \\
60 \text { to } 270 \mu \mathrm{m} \text {. }\end{array}$ \\
\hline $\begin{array}{l}44-2,74 \\
\text { (Extrusive) }\end{array}$ & 335,480 & $\begin{array}{l}\text { Skeletal (a few large anhedral grains); dark coatings and } \\
\text { corroded appearance; some staining around magnetite grains; } \\
\text { very tiny }(0.25-2 \mu \mathrm{m}) \text { sulfides. }\end{array}$ & $\begin{array}{l}1 \text { to } 5 \mu \mathrm{m} \text { and a few } 5 \text { to } \\
10 \mu \mathrm{m} \text {. }\end{array}$ \\
\hline $46-1,33$ & 280 & $\begin{array}{l}\text { Anhedral; moderate cracking; no staining: moderately } \\
\text { abundant sulfides, free and attached; a chrome spinel grain } \\
\text { present, edged with magnetite. }\end{array}$ & $\begin{array}{l}10 \text { to } 60 \mu \mathrm{m} \text {, some about } \\
5 \mu \mathrm{m} \text {. }\end{array}$ \\
\hline $51-1,24$ & 260 & $\begin{array}{l}\text { Anhedral; moderate to extensive cracking and some } \\
\text { uncracked; very slight staining; moderately abundant sulfides, } \\
\text { attached to and occasionally ringed with magnetite; chrome } \\
\text { spinel. }\end{array}$ & 60 to $140 \mu \mathrm{m}$. \\
\hline $52-1,128$ & 270 & $\begin{array}{l}\text { Skeletal and anhedral; cracking is slight to moderate; no } \\
\text { no staining; abundant sulfides; one large and several small } \\
\text { bright white grains (hematite-like) below polished surface. }\end{array}$ & Submicroscopic to $40 \mu \mathrm{m}$. \\
\hline $\begin{array}{l}56-1,57 \\
\text { (Extrusive) }\end{array}$ & 275 & $\begin{array}{l}\text { Skeletal; relatively uncracked; no staining; abundant sulfides, } \\
\text { occasionally with magnetite rimming. }\end{array}$ & $\begin{array}{l}0.5 \mu \mathrm{m} \text { (and possibly less) to } \\
\text { large elongated skeletal } \\
\text { (fishbone) structures of } \\
35 \text { to } 70 \mu \mathrm{m} \text { length. }\end{array}$ \\
\hline $\begin{array}{l}61-1,71 \\
\text { (Extrusive) }\end{array}$ & 340,485 & $\begin{array}{l}\text { Skeletal and anhedral; occasional cracking visible but } \\
\text { generally grains too small to observe cracking; some staining, } \\
\text { not excessive; moderate to scarce sulfides, but several very } \\
\text { large skeletal ones intergrown with skeletal magnetite. }\end{array}$ & $\begin{array}{l}\text { Submicroscopic to } 5 \mu \mathrm{m} \text {, } \\
\text { generally } 1 \text { to } 3 \mu \mathrm{m} \text {. }\end{array}$ \\
\hline $65-2,122$ & 275 & $\begin{array}{l}\text { Semi-skeletal and anhedral; moderate to slight cracking; no } \\
\text { staining; moderately abundant sulfides. }\end{array}$ & $\begin{array}{l}20 \text { to } 60 \mu \mathrm{m} \text { and some } 60 \text { to } \\
140 \mu \mathrm{m} \text {. }\end{array}$ \\
\hline $68-1,43$ & 300 & $\begin{array}{l}\text { Anhedral and some semi-subskeletal; slight to moderate } \\
\text { cracking; no staining; abundant sulfides. }\end{array}$ & $\begin{array}{l}\text { Generally } 3 \text { to } 60 \mu \mathrm{m} \text {, some } \\
90 \text { to } 250 \mu \mathrm{m} \text {. }\end{array}$ \\
\hline $\begin{array}{l}70-2,144 \\
\text { (Extrusive) }\end{array}$ & 305 & $\begin{array}{l}\text { Skeletal and anhedral; slight to some moderate cracking; very } \\
\text { slight staining; scarce (small) sulfides. }\end{array}$ & $\begin{array}{l}0.5 \text { to } 25 \mu \mathrm{m} \text {, generally } 3 \text { to } \\
12 \mu \mathrm{m} .\end{array}$ \\
\hline $75-2,139$ & 250 & $\begin{array}{l}\text { Anhedral, no cracking to very slight cracking; no staining; } \\
\text { abundant sulfides, free and attached to, or included in, } \\
\text { magnetite. }\end{array}$ & $\begin{array}{l}40 \text { to } 300 \mu \mathrm{m} \text { and some } 20 \\
\text { to } 40 \mu \mathrm{m} \text {. }\end{array}$ \\
\hline $80-3,91$ & 300 & $\begin{array}{l}\text { Skeletal and semi-skeletal; slight cracking but grains too small } \\
\text { to tell, some corrosion of grains; moderate staining; scarce } \\
\text { and small }(1-2 \mu \mathrm{m}) \text { sulfides. }\end{array}$ & 2 to $6 \mu \mathrm{m}$. \\
\hline $85-4,43$ & 265 & $\begin{array}{l}\text { Anhedral; slight cracking; no staining; abundant sulfides; } \\
\text { abundant ilmenite lamellae; two reflectivities of magnetite- } \\
\text { those rimming sulfides are darker gray; a few magnetites with } \\
\text { overgrowths noted. }\end{array}$ & 15 to $280 \mu \mathrm{m}$. \\
\hline $89-2,131$ & - & $\begin{array}{l}\text { Skeletal; somewhat corroded with dark coatings; no staining; } \\
\text { minor sulfides. }\end{array}$ & Submicroscopic to $5 \mu \mathrm{m}$. \\
\hline $90-4,124$ & 350,460 & $\begin{array}{l}\text { Anhedral and skeletal; extensive cracking with large replace- } \\
\text { ment within cracks; very slight staining but only around a few } \\
\text { sulfides; moderate to scarce sulfides. }\end{array}$ & $\begin{array}{l}1 \text { to } 20 \mu \mathrm{m} \text { and some } 60 \text { to } \\
150 \mu \mathrm{m} \text {, but because of } \\
\text { cracking, effective size is } 2 \\
\text { to } 12 \mu \mathrm{m} \text {. }\end{array}$ \\
\hline \multicolumn{4}{|l|}{ Hole 462} \\
\hline $60-2,33$ & $\begin{array}{l}255,405 \\
545\end{array}$ & $\begin{array}{l}\text { Skeletal; corroded with dark coatings; very slight staining; } \\
\text { sulfides very scarce. }\end{array}$ & $\begin{array}{l}1 \text { to } 40 \mu \mathrm{m} \text {, most commonly } \\
\text { S to } 25 \mu \mathrm{m} \text {. }\end{array}$ \\
\hline $63-1,89$ & 245,430 & $\begin{array}{l}\text { Skeletal and anhedral; cracking moderate to extensive with } \\
\text { notable replacement in cracks; staining noticeable; very sparse } \\
\text { sulfides. }\end{array}$ & $\begin{array}{l}\text { Commonly } 5 \text { to } 30 \mu \mathrm{m} \text {, and } \\
\text { some } 40 \text { to } 60 \mu \mathrm{m} \text {. }\end{array}$ \\
\hline $64-4,80$ & 155 & $\begin{array}{l}\text { Anhedral; moderate cracking; no staining; moderately } \\
\text { abundant sulfides; occasionally ringed by magnetite, ilmenite } \\
\text { fringing some magnetite grains and some weak lamellae and } \\
\text { patchy intergrowths. }\end{array}$ & 6 to $160 \mu \mathrm{m}$. \\
\hline $67-1,46$ & 490 & $\begin{array}{l}\text { Anhedral; minor cracking but notable replacement in the } \\
\text { cracks; small amount staining; moderate sulfides; abundant il- } \\
\text { menite lamellae and some growing on edges of magnetite } \\
\text { grains. }\end{array}$ & 0.5 to $200 \mu \mathrm{m}$. \\
\hline
\end{tabular}

Note: For explanation of descriptive terms, see text. 


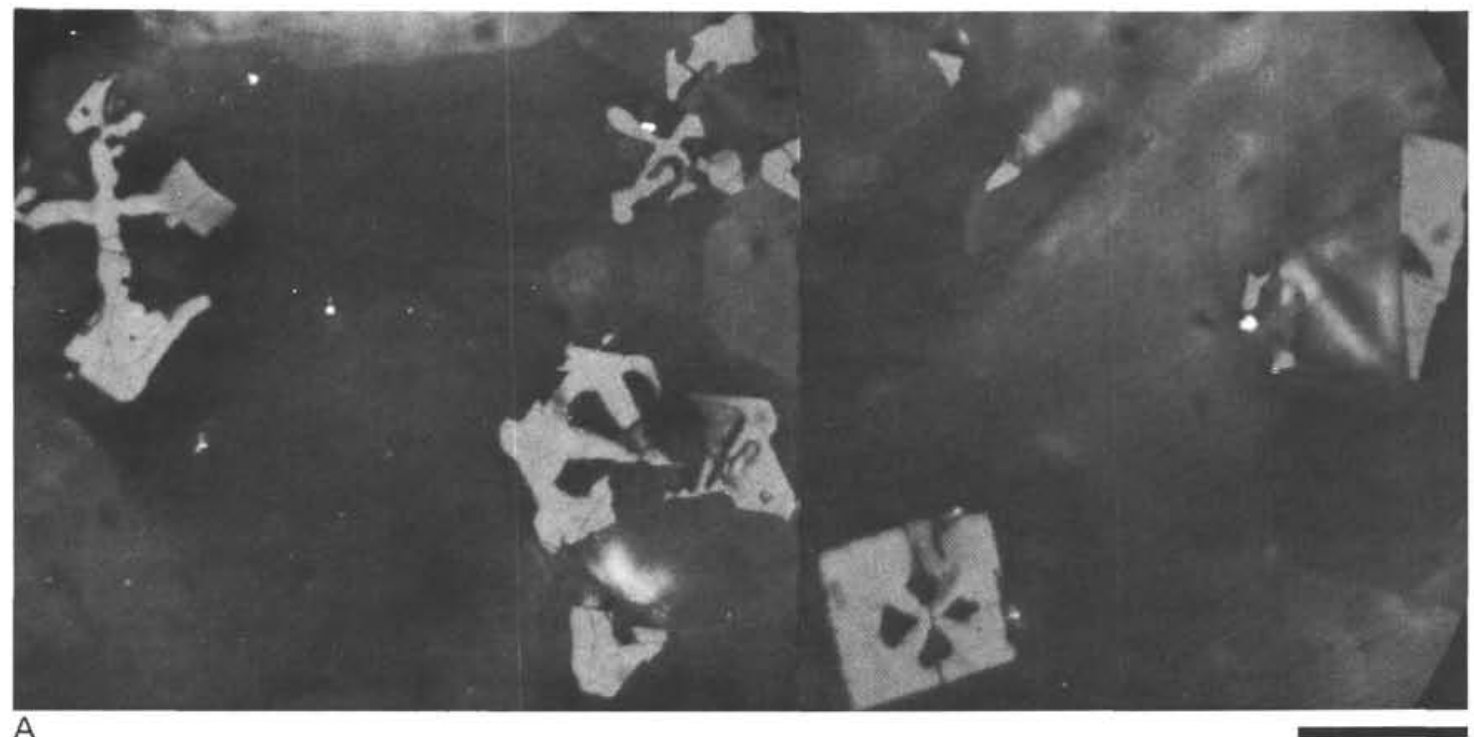

A

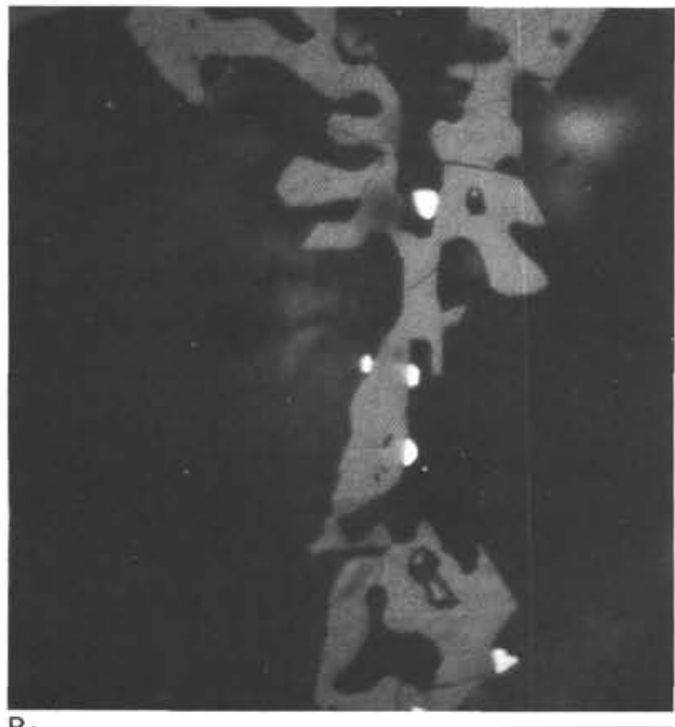

$\mathrm{B}_{1}$
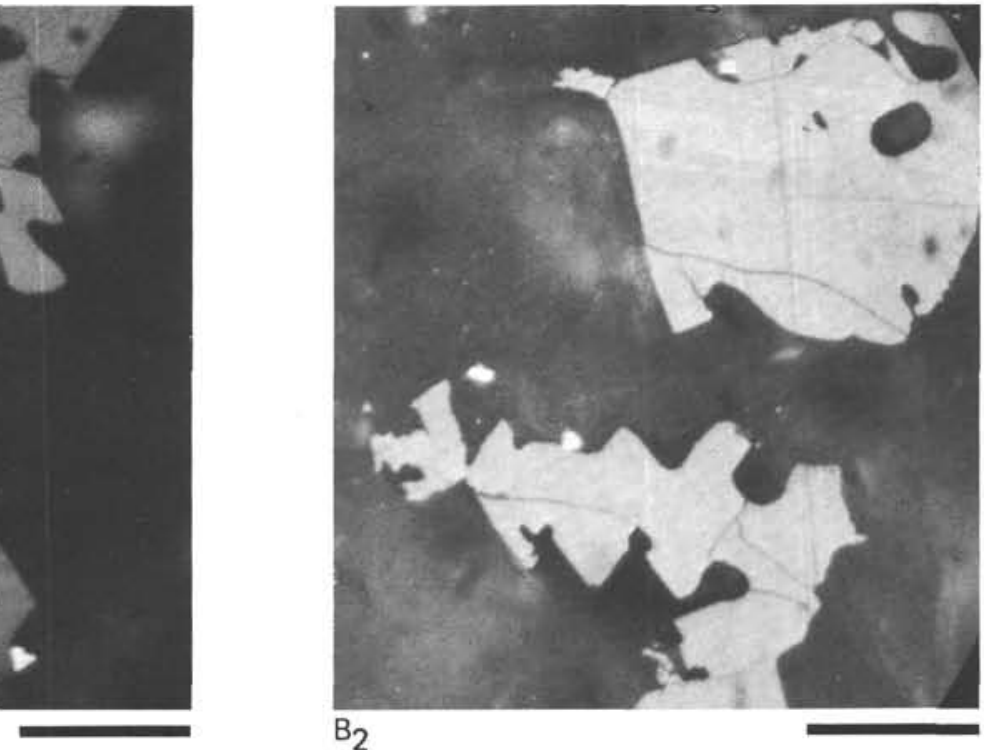

Figure 4. Shapes of titanomagnetite. Bar in photomicrographs $=20 \mu \mathrm{m}$. A. Skeletal (Sample 462A-20-2, $71 \mathrm{~cm}$ ). B. Semiskeletal $\left(\mathrm{B}_{1}=\right.$ Sample 462A-16-1, $29 \mathrm{~cm} ; \mathrm{B}_{2}=$ Sample $\left.462 \mathrm{~A}-22-3,50 \mathrm{~cm}\right)$.

patchy ilmenite growth and well-developed lamellae is demonstrated by Figure 7A. Patchy and fringing ilmenite also occur in samples taken above and below the positions of those containing the well-developed lamellae.

Figure 7 shows the more extensive lamellar development, observed in Samples $29-1,1 \mathrm{~cm}$ (Hole 462A) and $67-1,46 \mathrm{~cm}$ (Hole 462) and in Sample 85-4, $43 \mathrm{~cm}$ (Hole $462 \mathrm{~A})$. The first two of these samples probably belong to the same physical unit, a thick sill penetrated by both holes; both paleomagnetic and petrologic evidence suggest that they do (Steiner, this volume; Batiza et al., this volume). This unit is very thick, 51 meters in Hole $462 \mathrm{~A}$; its size, and therefore its higher heat retention after intrusion, may explain this occurrence of hightemperature oxidation.

Petrologic Unit 3 (Sample 19-1, $104 \mathrm{~cm}$ ) of Hole $462 \mathrm{~A}$ also has weak development of lamellae and frequent patchy ilmenite intergrown with TM. Petrologic unit 42 (Sample $85-4,43 \mathrm{~cm}$ ) is the third occurrence of ilmenite lamellae observed in this igneous suite. Unit 42 is also a thick $(18 \mathrm{~m})$ sill, but Unit $3(4.5 \mathrm{~m})$ is not. Further, Units $24(21 \mathrm{~m})$ and $32(25 \mathrm{~m})$, additional thick sill units, were examined but did not have developed lamellae. All but one of the thick sills in Hole 462A have been examined optically. The apparently irregular occurrence of high-temperature oxidation represented here may have a simple explanation. 

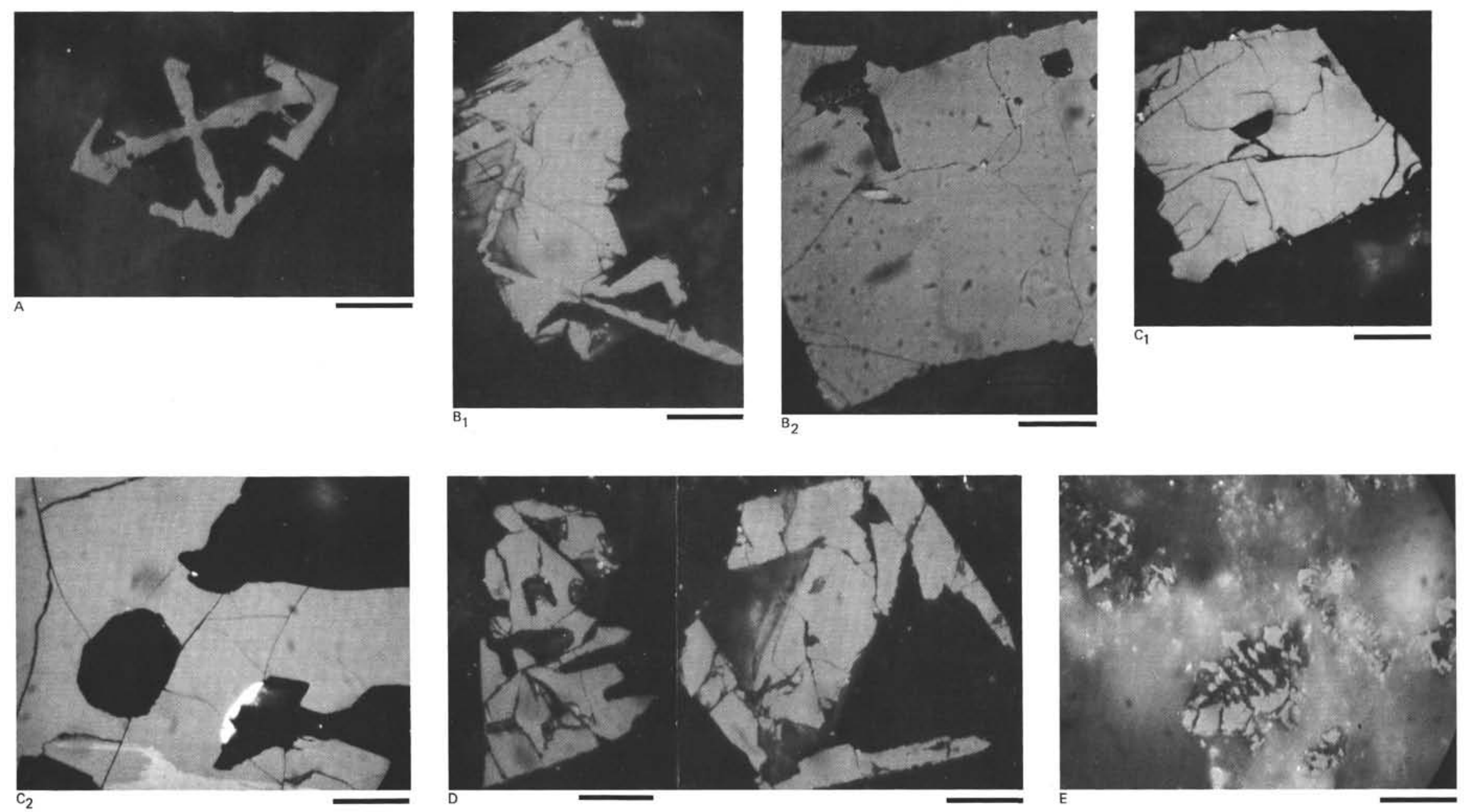

Figure 5. Types of cracking within titanomagnetites. Bar in photomicrographs $=20 \mu \mathrm{m}$. A. Slight cracking (Sample 462A-65-2, $122 \mathrm{~cm}$ ). B. Moderate cracking (B $B_{1}=$ Sample $462 \mathrm{~A}-85-4,44 \mathrm{~cm}$; $B_{2}=$ Sample 462A-52-1, $\left.128 \mathrm{~cm}\right)$. C. Extensive cracking $\left(C_{1}=\right.$ Sample 462A-41-4, $103 \mathrm{~cm} ; C_{2}=$ Sample $\left.462 \mathrm{~A}-41-6,42 \mathrm{~cm}\right)$. D. Extensive cracking with replacement within the cracks $($ Sample $462 \mathrm{~A}-90-4,125 \mathrm{~cm}$ ). E. Corrosion of small grains and the accompanying dark exteriors (Sample $462-60-2,33 \mathrm{~cm}$ ). 

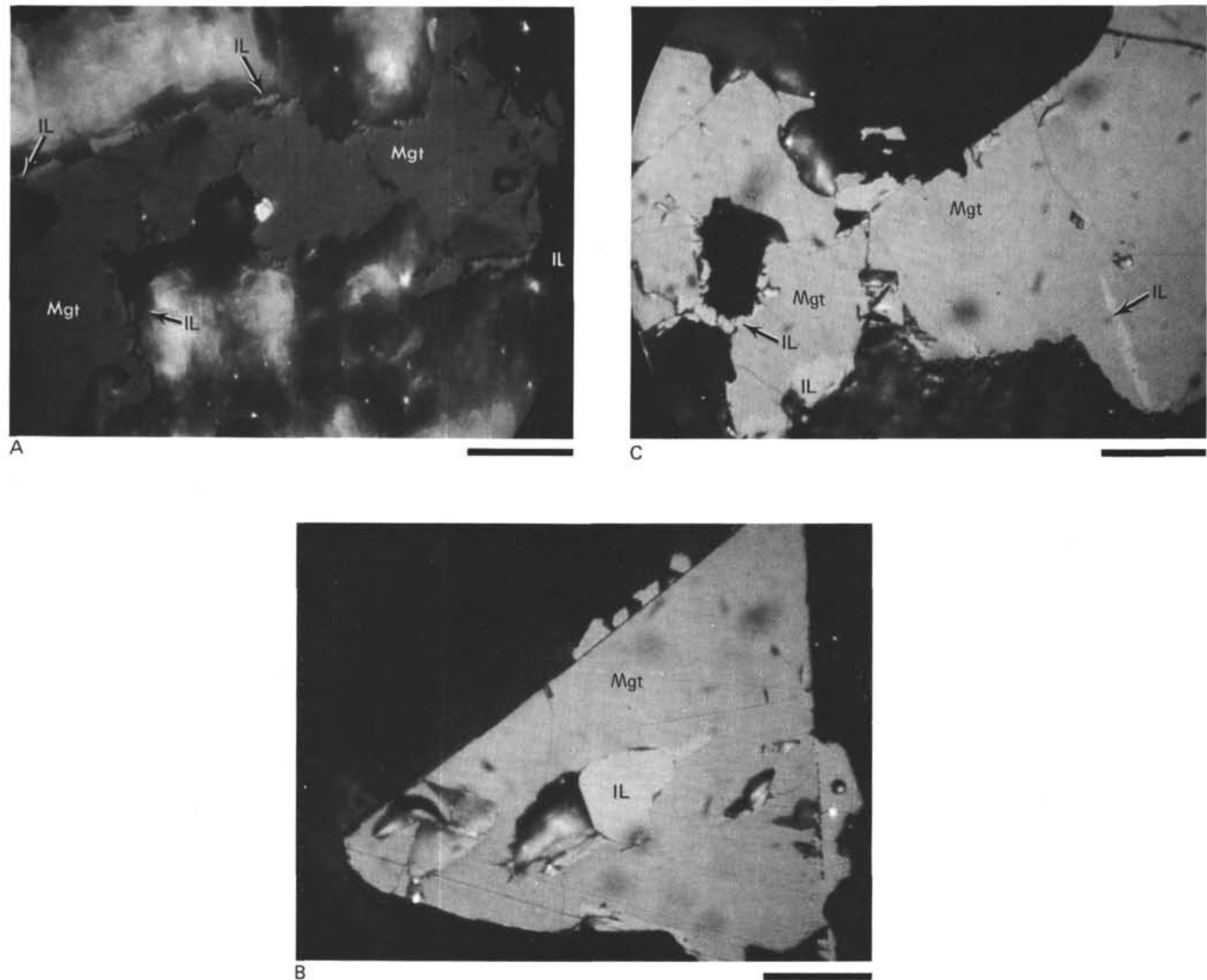

Figure 6. Occurrences of ilmenite associated with titanomagnetite. All photomicrographs are through crossed nicols. Bar in photomicrographs $=$ $20 \mu \mathrm{m}$. A. Ilmenite (light) on the edges of Ti-magnetite (darker). Bright spot in center is Fe sulfide. (Sample 462A-19-1, 104 cm). B. Patches of ilmenite (light) on the edges of Ti-magnetite and one lamella of ilmenite (right). (Sample 462A-28-1, $84 \mathrm{~cm}$ ). C. Central inclusion of ilmenite (light) in Ti-magnetite (Sample 462A-28-1, $84 \mathrm{~cm}$ ).

The medium into which intrusion took place may have a bearing on the presence or absence of ilmenite patches and lamellae. On the one hand, both of the examined thick sills which lack lamellae (Units 24 and 32) were intruded among extrusive flow units, and cooling may have been more rapid. The ilmenite-bearing samples, on the other hand, were taken from the middle of large thicknesses of intrusive material. As discussed in the case of Samples 462A-28-1, $84 \mathrm{~cm}$ and 462A-29-1, 1 $\mathrm{cm}$, they were recovered from the center of a single very thick sill unit. Sample $462 \mathrm{~A}-85-4,43 \mathrm{~cm}$ is likewise from the center of the 18-meter-thick Unit 42. Even the third occurrence, represented by Sample 462A-19-1, $104 \mathrm{~cm}$, is from the center of thin Unit 3, but this 4.5-meter sill is the medial unit in the stack of intrusives at the top of Hole 462A. Petrologic Units 1-9 comprise a series of intrusives 27 meters thick, bounded by sedimentary intervals on both sides. (This is shown in a diagram in the
Site Summary, this volume.) These various sample positions suggest the very plausible hypothesis that the pattern of occurrence of ilmenite lamellae may be an indicator of the heat-retention characteristics of the environments around the samples, reflecting either thermal properties of the medium into which the sill unit intruded, or the thickness of the sill itself (as with Unit 12).

\section{ELECTRON MICROPROBE}

The microprobe used is a Materials Analysis Corporation microprobe, model 5-SA3. It is interfaced with a PDP-8/L computer and operated under computer control. It is equipped with three spectrometers, and computer control allows a maximum counting time of two minutes on each element. Each grain examined was analyzed for $\mathrm{Fe}, \mathrm{Ti}, \mathrm{Mg}, \mathrm{Al}, \mathrm{Mn}, \mathrm{Cr}, \mathrm{Zr}$, and $\mathrm{Si}$. A standard of magnetite was also analyzed. The magnetite 


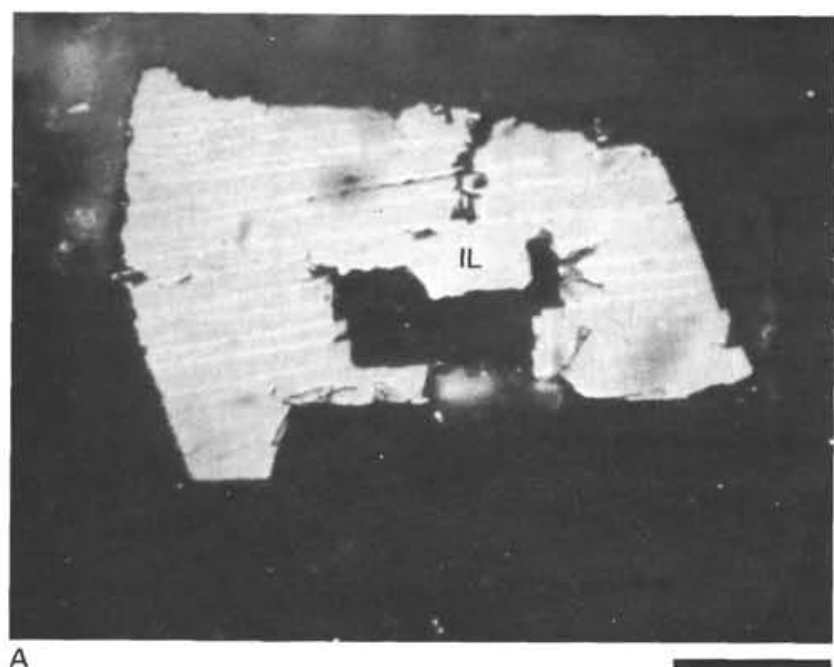

A

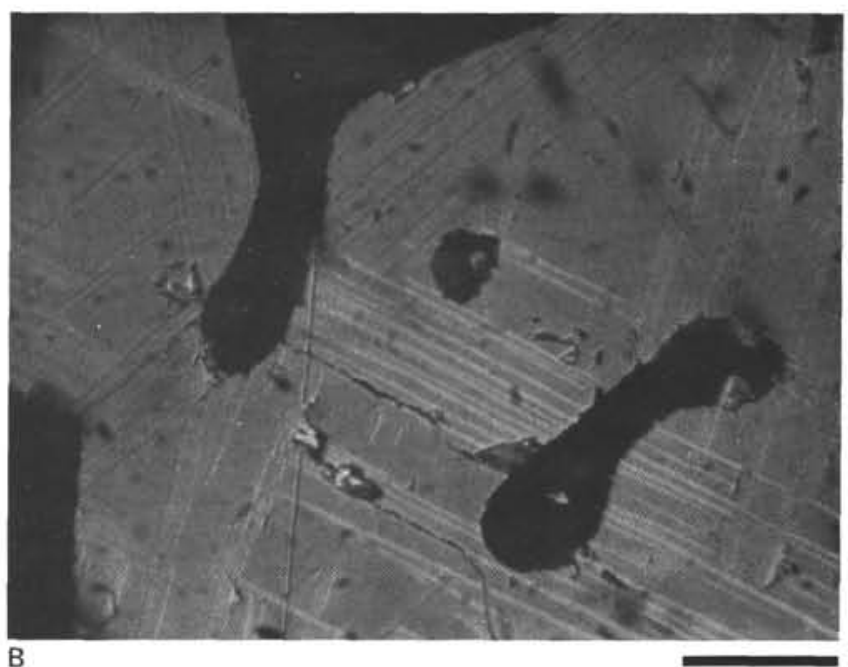

B

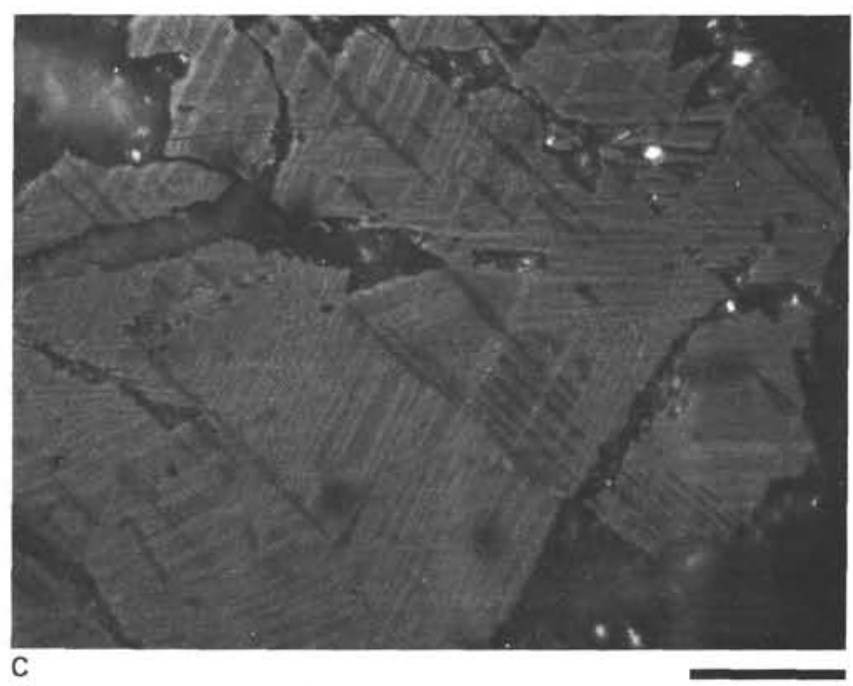

Figure 7. Well-developed ilmenite in titanomagnetite. Bar in photomicrographs $=20 \mu \mathrm{m}$. A. Single direction of lamellar development in association with a large central patch of ilmenite (central light rectangular piece of the grain). Plane-polarized light. (Sample 462A-29-1, $1 \mathrm{~cm}$ ). B, C. Ilmenite lamellae along all three (111) crystallographic planes of titanomagnetite. Cross-polarized light. $\mathrm{B}=\mathrm{Sample} 462 \mathrm{~A}-85-4,44 \mathrm{~cm} . \mathrm{C}=$ Sample 462-67-1, $46 \mathrm{~cm}$.

gave a total of $93.97 \mathrm{wt} . \%$, as expected for pure magnetite when all iron is calculated as FeO. Three to five widely separated grains were analyzed for each sample. Generally, three analyses were done on each grain, usually one in the center and two near the edges of the grain, although some grains were too small to accommodate three analyses. Sample $462 \mathrm{~A}-41-4,103 \mathrm{~cm}$ has received only one analysis per grain so far.

The results of the four preliminary sample analyses are shown in Table 3. These samples are from the uppermost intrusives and the sills in the central sedimentary interval. Insignificant amounts of zirconium, chromium, and $\mathrm{SiO}_{2}$ are present. (Four analyses containing $>0.19$ wt. $\% \mathrm{SiO}_{2}$ have been excluded from the table.) Significant amounts of aluminum are present in every sample, usually 1 to $2 \mathrm{wt}$. \%. Magnesium and manganese occur in every sample, but at values of less than 0.7 wt. $\%$ each.
Table 3. Electron microprobe analyses, Hole $462 \mathrm{~A}$ samples.

\begin{tabular}{ccccccc}
\hline $\begin{array}{c}\text { Core-Sec., } \\
\begin{array}{c}\text { Sample Position } \\
(\mathrm{cm})\end{array}\end{array}$ & $\begin{array}{c}\text { Curie } \\
\text { Temp. } \\
T_{c}\left({ }^{\circ} \mathrm{C}\right)\end{array}$ & $\begin{array}{c}\text { No. Grains } \\
\text { Analyzed }\end{array}$ & $\begin{array}{c}\text { Total } \\
\text { Analyses }\end{array}$ & $\begin{array}{c}\text { Mean } \\
\text { Ti/Fe }\end{array}$ & $\begin{array}{c}\text { Standard } \\
\text { Deviation }\end{array}$ & $\begin{array}{c}X \text { in } \\
\text { Fe3-X } \\
(\times 100)\end{array}$ \\
\hline $16-1,29$ & 170 & $\left.4(3)_{4}\right)_{4}$ & 10 & $0.27077 \pm 0.01077$ & 63.9 \\
$19-1,104$ & 215 & $3(3)$ & 9 & $0.27849 \pm 0.00245$ & 65.3 \\
$41-4,103$ & 240 & $3(3)$ & 3 & $0.27653 \pm 0.01308$ & 65.0 \\
$41-6,42$ & 210 & $5(5)$ & 13 & $0.28065 \pm 0.00577$ & 65.7 \\
\hline
\end{tabular}

a Number of grains used in calculations.

The titanium compositional parameter $x$ in the formula $\left(\mathrm{Fe}_{3-x} \mathrm{Ti}_{x} \mathrm{O}_{4}\right)$ has been calculated from the $\mathrm{TiO}_{2}$ / $\mathrm{FeO}$ ratios (Table 3). It is interesting that Sample 462A19-1, $104 \mathrm{~cm}$, which contains some poorly developed ilmenite lamellae and patchy ilmenite growth in the titanomagnetite, does not have an $x$-value different from the other samples. As shown in Table 3, the four samples analyzed have a very narrow range of $x$-values, about 0.65 . Individual analyses within grains yielded $x$ 
from 0.60 to 0.68 . These values are in the range reported in most studies of oceanic basalts (see, for example, Peterson, 1976; Johnson and Melson, 1979). Thus, in yet another characteristic, these igneous rocks appear quite similar to those of the oceanic crust.

\section{DISCUSSION}

Both the thermomagnetic measurements and microscopic appearance of these samples suggest that they have been relatively little affected by the low-temperature oxidation process. Curie points are generally between 150 and $350^{\circ} \mathrm{C}$, and most are near $270^{\circ} \mathrm{C}$ (Fig. 8). The extrusive rocks made up the high end of the histogram of Curie temperatures in Figure 8. The samples whose titanomagnetite grains show the most cracking and staining under the microscope have the highest Curie temperatures. Unlike samples used in previous microscopic observations by Johnson (1979b), however, those with the least (or no) cracking or staining do not have the lowest Curie temperatures. My samples show little difference in cracking of grains having Curie temperatures between 150 and $300^{\circ} \mathrm{C}$. Likewise, the yellow and red staining of the silicates, found by Johnson $(1979 b)$ in samples with Curie temperatures above $275^{\circ} \mathrm{C}$, is uncommon in all but a few of the samples of this study. Even in those samples having $T_{c}$ near $350^{\circ} \mathrm{C}$, staining is not as significant as that described by Johnson. This is true in both the upper intrasives and the lower extrusive/intrusive sequence. This may indicate that variations of titanium originally existed within the titanomagnetites and have influenced the Curie temperatures. Alternatively, there may not be a perfect correlation between the onset of cracking or staining and the increase in the Curie point.

The primary recognition resulting from this study is that these rocks have experienced only a small amount of low-temperature oxidation, despite their apparent Early Cretaceous origins. For Lower and Upper Cretaceous extrusive basalts, Marshall (1978) and Levi (S. Levi, personal communication) have found Curie temperatures of 300 to $400^{\circ} \mathrm{C}$. The somewhat lower Curie temperatures of samples from Site $\mathbf{4 6 2}$ may be readily explained by the large grain size of the samples and the massiveness of many of the sills. Earlier studies have emphasized the inverse relationship of grain size and degree of low-temperature oxidation (Johnson and Hall, 1978; Day et al., 1979). In contrast to most studies, which deal with pillow basalts, this study in-

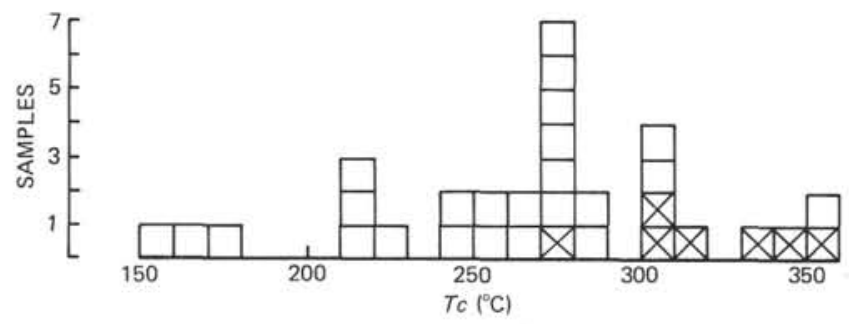

Figure 8. Histogram of Curie-point values for Holes 462 and 462A. Crosses indicate extrusive rocks. vestigates largely intrusive material. The extrusive material of this investigation has Curie temperatures in general agreement with those determined in other studies of material of comparable age. The relationship of the grain size/permeability relationship to oxidation is also further demonstrated in this investigation. Samples dominated by small grains (1-5 $\mu \mathrm{m})$ or grains highly divided by cracks are also samples having high Curie temperatures. Samples with slight staining or lesser amounts of sulfides are also those in which the titanomagnetite grain size is smallest. Thus, study of these igneous rocks reinforces previous findings in suggesting that the massiveness of the sills and/or the coarse grain size of the rocks inhibit low-temperature oxidation.

\section{ACKNOWLEDGMENTS}

P. N. Shive and S. K. Bannerjee reviewed this paper. Their comments have greatly improved the text.

\section{REFERENCES}

Ade-Hall, J. M., Fink, L. K., and Johnson H. P., 1976. Petrography of opaque minerals, Leg 34. In Yeats, R. S., Hart, S. R., et al., Init. Repts. DSDP, 34: Washington (U.S. Govt. Printing Office), 349-362

Day, R., Halgedahl, S., Steiner, M., et al., 1979. Magnetic properties of basalts from Leg 49. In Luyendyk, B. P., Cann, J. R., et al. Init. Repts. DSDP, 49: Washington (U.S. Govt. Printing Office), 781-792.

Doell, R. R., and Cox, A., 1965. Measurement of the remanent magnetization of igenous rocks. Geol. Surv. Bull. (U.S.) 1203-A, 1-32.

Eisenach, P., 1978. Petrography of opaque minerals in basalts drilled on DSDP Leg 45. In Melson, W. G., Rabinowitz, P. G., et al., Init. Repts. DSDP, 45: Washington (U.S. Govt. Printing Office), 557-573.

Freer, R., and Hauptman, Z., 1978. An experimental study of magnetite-titanomagnetite interdiffusion. Earth Planet. Sci. Lett., 16: 223-231

Grommé, C. S., and Mankinen, E. A., 1976. Natural remanent magnetization, magnetic properties, and oxidation of titanomagnetite in basaltic rocks from DSDP Leg 34. In Yeats, R. S., Hart, S. R., et al., Init Repts. DSDP, 34: Washington (U.S. Govt. Printing Office), 485-494.

Grommé, C. S., Wright, T. L., and Peck, D. L., 1969. Magnetic properties and oxidation of iron-titanium oxide minerals in Alae and Makaopuhi lava lakes, Hawaii. J. Geophys. Res., 74:52775293.

Hall, J. M., and Fischer, J. F., 1977. Opaque mineralogy of basement rocks, Leg 37. In Aumento, F., Melson, W. G., et al., Init. Repts. DSDP, 37: Washington (U.S. Govt. Printing Office), 857-873.

Honnorez, J., Böhlke, J. K., Honnorez-Guerstein, B. M., et al., 1978. Correlation between the changes in the mineralogy, chemistry, and magnetic properties of basalts from DSDP Leg 46 with low temperature submarine alteration. In Dmitriev, L., Heirtzler, J., et al., Init. Repts. DSDP, 46: Washington (U.S Govt. Printing Office), 371-376.

Johnson, H. P., 1979a. Rock magnetic properties of igenous rock samples-Leg 45. In Melson, W. G., Rabinowitz, P. G., et al., Init. Repts. DSDP, 45: Washington (U.S Govt. Printing Office), 397-406.

, 1979b. Opaque mineralogy of the igneous samples from DSDP Hole 395A. In Melson, W. G., Rabinowitz, P. G., et al., Init. Repts. DSDP, 45: Washington (U.S. Govt. Printing Office), 407-420.

Johnson, H. P., and Hall, J. M., 1978. A detailed rock magnetic and opaque mineralogy study of the basalts from Nazca Plate. Geophys. J., 52:45-64.

Johnson, H. P., and Melson, W. G., 1979. Electron microprobe analyses of some titanomagnetite grains from Hole 395A. In Melson, W. G., Rabinowitz, P. G., et al., Init. Repts. DSDP, 45: Washington (U.S. Govt. Printing Office), 575-579. 
Marshall, M., 1978. The magnetic properties of some DSDP basalts from the North Pacific and inferences for Pacific plate tectonics. J. Geophys. Res., 83:289-308.

Peterson, N., 1976. Notes on the variation of magnetization within basalt flows and dikes. Pure Appl. Geophys., 114:177-193.
Schlanger, S. O., and Jenkyns, H. C., 1976. Cretaceous oceanic anoxic events: Causes and consequences. Geol. en Mijnbouw, 55: 179-184. 